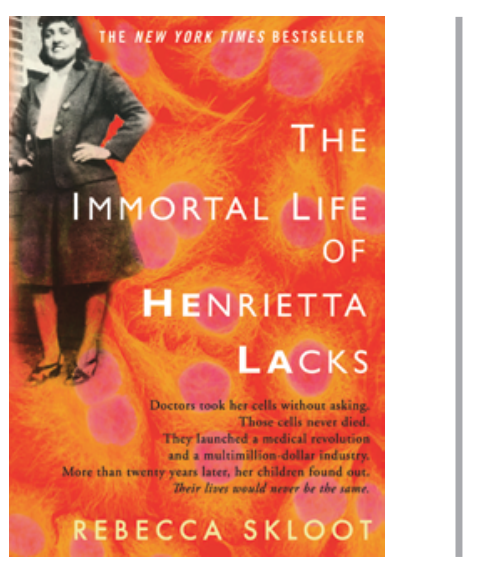

\title{
The immortal life of Henrietta Lacks
}

\author{
Rebecca Skloot \\ Random House Inc. New York, New York, USA. 2010. \\ 384 pp. \$26.00. ISBN: 978-1-4000-5217-2 (hardcover).
}

Reviewed by Stacie Bloom

The New York Academy of Sciences, New York, New York, USA.

E-mail: sbloom@nyas.org must start off this review by admitting that although I had seen this book reviewed in publications ranging from the New York Post to Entertainment Weekly magazine and everything in between, I guessed that $\mathrm{I}$, as a scientist trained in cell biology, would not enjoy it. What could I possibly learn? I assumed that a book on the subject of HeLa cells written for the general public would be beneath me. Boy, was I ever wrong.

The Immortal Life of Henrietta Lacks is the astonishing biography of a poor tobacco farmer whose cells, first grown in culture in 1951, are still ubiquitous in the laboratory world today. The author, Rebecca Skloot, dedicated nearly a decade to researching the science and, perhaps more interestingly, getting to know the Lacks family. Skloot is a science journalist whose name is familiar in the corridors of my own institution, the New York Academy of Sciences, because she did freelance work for us, writing about our scientific symposia. With this book, she presents an unforgettable story that reads like a novel.

Henrietta Lacks was a 29-year-old mother when doctors at Johns Hopkins diagnosed her with aggressive cervical cancer. At that time, Hopkins was the only hospital nearby that would admit and treat African American patients. Without her consent, as was commonly done in that time, doctors removed a sample of her cancerous tissue and gave it to a laboratory that had been trying for years to grow an immortalized human cell line. They named the cells HeLa, consistent with their practice of abbreviating the first and last names of the patient, and without informing her or her family put them in a dish.

Anyone who has come from a basic science laboratory knows where the story is going. Of course, the heartiness of HeLa cells in culture and their ability to be grown in suspension, easily freezethawed, and shipped provided the scientific community for the very first time with a consistent and reliable tool for experimentation that revolutionized the way we do research. HeLa cells have been used in so many groundbreaking studies that it would be hard to overstate their importance to science and medicine. The cells were used to launch the field of virology, to create the polio vaccine, to do gene mapping and cloning, and to study the effects of zero gravity in outer space and in a slew of other studies that add nearly 300 new publications each month to a library that now totals about 60,000 .

And it goes without saying that the launch of reliable cell culture provided novel financial opportunities to the pharmaceutical industry. Billions of these cells have since been bought and sold, not to mention the culture medium used to grow them and the related biological materials and laboratory equipment needed.

Henrietta Lacks died eight months after her diagnosis, leaving behind five small children, including a one-year-old daughter, Deborah. The family, still oblivious to the fact that her cells were thriving in vitro after her death, buried her in an unmarked grave on their land in Virginia, too poor to even buy a headstone.
In a random twist of fate nearly two decades later, the family learned about the cell line bearing their mother's initials. This book focuses on the story of the family - the offspring of this unintentional heroine who are raised in dire poverty and often without medical insurance, who can only explain the permanence of the living cells as voodoo, and who are taken advantage of. Over time, Skloot develops a close relationship with Deborah and helps her pour over biology textbooks and muddle through jargon until she can understand the concept of the cells and be convinced that her mother has not been and cannot be cloned. Skloot brings Deborah and her brother to Christoph Lengauer's then laboratory at Hopkins to see the cells under a microscope for the first time. And all the while, Henrietta's grown children ponder the absurdity of how they can't afford to see a doctor when their mother's cells have helped cure so many diseases and when industry is making a fortune. The family has never been compensated financially in any way.

Skloot expertly interweaves this heartbreaking family story with the inspirational story of the cell line and the disturbing tale of the ethical and legal issues surrounding treatment of African American patients at mid-century. Skloot provides just enough background information for the reader to appreciate the materialization of federal laws regulating the use of human subjects in experimentation.

The result is one comprehensive and hauntingly beautiful story. No matter how much you may know about basic biology, you will be amazed by this book. 